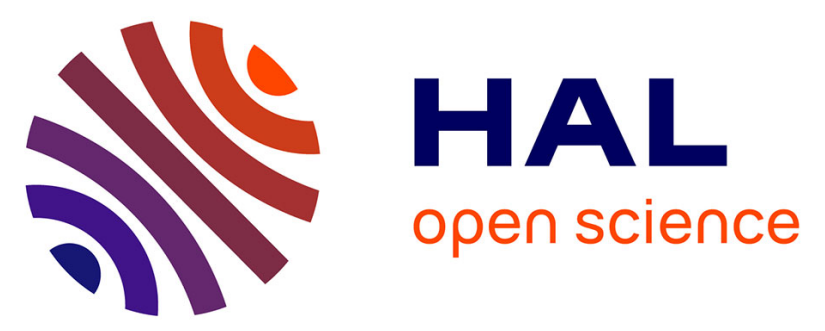

\title{
MALDI-MS Direct Tissue Analysis of Proteins: Improving Signal Sensitivity Using Organic Treatments
}

R. Lemaire, M. Wisztorski, A. Desmons, J. C. Tabet, R. Day, M. Salzet, Isabelle Fournier

\section{- To cite this version:}

R. Lemaire, M. Wisztorski, A. Desmons, J. C. Tabet, R. Day, et al.. MALDI-MS Direct Tissue Analysis of Proteins: Improving Signal Sensitivity Using Organic Treatments. Analytical Chemistry, 2006, 78 (20), pp.7145 -7153. 10.1021/ac060565z . hal-00086901

\section{HAL Id: hal-00086901 https://hal.science/hal-00086901}

Submitted on 18 Aug 2007

HAL is a multi-disciplinary open access archive for the deposit and dissemination of scientific research documents, whether they are published or not. The documents may come from teaching and research institutions in France or abroad, or from public or private research centers.
L'archive ouverte pluridisciplinaire HAL, est destinée au dépôt et à la diffusion de documents scientifiques de niveau recherche, publiés ou non, émanant des établissements d'enseignement et de recherche français ou étrangers, des laboratoires publics ou privés. 


\title{
MALDI-MS DIRECT TISSUE ANALYSIS OF PROTEINS:
}

\section{IMPROVING SIGNAL SENSITIVITY USING ORGANIC TREATMENTS}

\author{
R. Lemaire ${ }^{1,2}$, M. Wisztorski ${ }^{1}$, A. Desmons ${ }^{1}$, J.C. Tabet $^{2}$, R. Day ${ }^{3}$, M.Salzet ${ }^{1}$, I. Fournier ${ }^{1 *}$ \\ *Corresponding Author
}

${ }^{1}$ Laboratoire de Neuroimmunologie des Annélides, FRE CNRS 2933, Bât SN3, $1^{\text {er }}$ étage, Université des Sciences et Technologies de Lille, 59655 Villeneuve d’Ascq Cedex, France

${ }^{2}$ Synthèse, Structure et Fonction de Molécules Bioactives, UMR-CNRS 7613, Boite 45, Université Pierre et Marie Curie, 4 place Jussieu, 75252 Paris Cedex 05, France

${ }^{3}$ Département de Pharmacologie, Faculté de médecine, Université de Sherbrooke, Sherbrooke, Québec, J1H 5N4, Canada

\section{ABSTRACT}

Direct tissue analysis using MALDI-MS allows the generation of profiles while maintaining the integrity of the tissue, displaying cellular localizations and avoiding tedious extraction and purification steps. However, lower spectral quality can result from direct tissue analysis due to variations in section thickness, the nature of the tissue and the limited access to peptides/proteins due to high lipid content. In order to improve signal sensitivity, we have developed a tissue washing procedure using organic solvents traditionally used for lipid extraction i.e. $\mathrm{CHCl}_{3}$, hexane, toluene, acetone and xylene. The increased detection for peptides/proteins (m/z 5000-30000) is close to $40 \%$ with chloroform or xylene, and $25 \%$ with hexane, while also improving sample reproducibility for each solvent used in the present study. This strategy improved matrix co-crystallization with tissue peptides/proteins and more importantly with cytoplasmic proteins without delocalization. The extracted lipids were characterized by nanoESI-QqTOF/MS/MS using the precursor ion mode and/or lithium adducts and were identified as phospholipids including phosphatidylcholine, 
phosphatidylethanolamine, phosphatidylinositol and lysophosphatidylinositol confirming membrane lipid extraction from the tissues. 


\section{INTRODUCTION}

Matrix Assisted Laser Desorption Ionization (MALDI) ${ }^{1,2}$ is now an extensively used and hard to circumvent technique for biomolecular analysis of peptides/proteins, glycoproteins, sugars, lipids and even oligonucleotides. It is a revolutionary technology for proteomic studies when combined with traditional separation techniques such as gel electrophoresis or liquid chromatography. However, such strategies lead to the lost of the localization of the biomolecules inside the tissue. Using direct analysis of tissues and by extension molecular imaging by mass spectrometry this difficulty can be overcome ${ }^{34}$. Since, its introduction by Caprioli and collaborators, MALDI direct analysis and imaging of peptides/proteins were successfully used for the analyses of different tissues and different applications ${ }^{4-8}$. More recently, MALDI imaging has been extended to lipids and drugs analysis 9, 10 11-15. Several fundamental developments have also contributed to improvements in MALDI imaging performance both in instrumentation, sample preparation and informatics treatment. Several applications have already been established for this technology for drug biodistribution studies $^{13,16}$, biomarker discovery or for understanding molecular mechanism ${ }^{4,6,17,18}$. The application of MALDI imaging is a promising technique for pathologies such as cancers or diseases related to ageing or metabolic disorders.

Increasing the representativity and the reproducibility of analysis is difficult since tissues are highly complex matrices including a wide range of biomolecules such as peptides/proteins, oligonucleotides, sugars, lipids present in various quantities. In this regard, tissue sections are more complex samples to analyze than separated and/or purified ones. For example, it is observed that analytical quality, especially for peptides/proteins is excellent for freshly dissected tissue samples but that signal intensity decreases drastically with the length of time of conservation. Signal decrease is due to a low signal to noise ratio and poor reproducibility. After one year storage, even at $-80^{\circ} \mathrm{C}$, it is difficult to obtain good 
peptides/proteins spectra for tissues. This phenomenon of tissue ageing must be pointed out when experiments in direct profiling or MALDI imaging are undertaken. In fact, it is not always possible to analyze freshly prepared samples especially when working in the clinical field, where samples are difficult to collect and are stored in centralized tissue repositories. It is therefore of even greater importance to find tissue treatments that can ensure a good signal for peptides/proteins from such samples by MALDI. In a previous publication, the addition of an ethanol washing step was introduced to reduce salts and hemoglobin contaminants on the tissue surface ${ }^{19}$. In order to make further improvements, compatible with protein profiling, we tested washing tissues with organic solvents traditionally used for lipids extraction e.g. chloroform $^{20,21}$, hexane ${ }^{22}$ or xylene. This strategy resulted in marked improvements of matrix access to peptides and proteins in the tissue sections and more particularly to the ones located in the cytoplasm without any delocalization of the proteins. 


\section{EXPERIMENTAL}

\section{Material}

a-cyano-4-hydroxycinnamic acid (HCCA), sinapinic acid (SA), Angiotensin II, Des-ArgBradykinin, Substance P, ACTH 18-39, ACTH 7-38 and bovine Insulin were obtained from Sigma-Aldrich and used without any further purification. Trifluoroacetic acid (TFA) was purchased from Applied Biosystems. Acetonitrile p.a. and methanol p.a. from J.T. Baker.

\section{Tissue preparation}

Adult male Wistar rats weighing 250-350 g (animal welfare accreditation by the French ministry of the agriculture $\mathrm{N}^{\circ}$ 04860) maintained under standard care were used. Animals were sacrificed by decapitation and immediately dissected to remove the brain. Frozen sections of $15 \mu \mathrm{m}$ were performed on a cryostat and immediately transferred onto the MALDI stainless steel plate. The matrix solution was applied to several sections after ten minutes of drying at room temperature. The rest were kept for organic solvent treatments prior to matrix deposition and MALDI analysis.

\section{Tissue treatment}

Tissue sections were quickly rinsed using different organic solvent. Typically, the rinsing was performed with a glass syringe, using twice $200 \mu \mathrm{L}$ of solvent per $\mathrm{cm}^{2}$ of tissue. During the operation, the MALDI plate was inclined to drain excess solvent and remove impurities or compounds extracted by the treatment. After complete drying, matrix was applied onto the tissue and dried at room temperature before MALDI analysis. 


\section{Mass Spectrometry}

\section{MALDI-MS Direct Analysis}

MALDI-TOF mass spectra were performed on a Voyager-DE STR mass spectrometer (Applied Biosystems, Framingham, MA, USA) with delayed extraction (DE) and a 337nm pulsed nitrogen laser. Either HCCA or SA were used at concentration's of $10 \mathrm{mg} / \mathrm{mL}$ and 20 $\mathrm{mg} / \mathrm{mL}$ respectively, in ACN /0.1\% TFA: $\mathrm{H}_{2} \mathrm{O}(2: 1, \mathrm{v} / \mathrm{v})$. Both matrices were applied onto the tissue using a micropipette (typically $20 \mu \mathrm{L}$ for a whole rat brain slice) and then dried at room temperature. For compounds with $\mathrm{m} / \mathrm{z}<10$ 000, HCCA matrix was used and external calibration was performed using a mixed solution of peptides (bradykinin $1.6 \mu \mathrm{M}$, Substance P $1.6 \mu \mathrm{M}$, ACTH 18-391.6 $\mu \mathrm{M}$, ACTH 7-383.2 $\mu \mathrm{M}$, bovine Insulin $4.8 \mu \mathrm{M}$ and bovine Ubiquitin $4.8 \mu \mathrm{M}$ in $\mathrm{H}_{2} \mathrm{O}$ ). For higher masses, SA was preferred as matrix and hemoglobin chain $\alpha$ (major) and hemoglobin chain $\beta$ (major) peaks were used as internal calibrants ${ }^{5}$. Slices were visualized in the mass spectrometer using a color CCD camera (SONY). Each recorded mass spectrum is resulting from the average of 200 laser shots on the area of interest. Acquisition parameters were set as follow

-HCCA matrix (mass range 1000-10000): acceleration voltage: $25 \mathrm{kV}, 1^{\text {st }}$ grid voltage: 94\%, guide-wire voltage: $0.05 \%$, extraction delay time: 200 ns.

-SA matrix (mass range 2000-30000): acceleration voltage: $25 \mathrm{kV}, 1^{\text {st }}$ grid voltage: $94 \%$, guide-wire voltage: $0.2 \%$, extraction delay time: $300 \mathrm{~ns}$.

\section{MALDI Imaging experiments}

For MALDI-IMS, imaging was performed on an Ultraflex LIFT-TOFTOF (Bruker Daltonics, Bremen, DE) using the ionic matrix HCCA/ANI for peptides (below 5000 Da) in positive reflector mode ${ }^{15}$, and sinapinic acid (20mg in ACN/TFA 0,1\% in $\mathrm{H}_{2} \mathrm{O}(1: 1, \mathrm{v} / \mathrm{v})$ ) for compounds over $5000 \mathrm{Da}$ in positive linear mode. For a better crystallization on the tissue, the 
ionic matrix was prepared by increasing the volume of base (1.5 eq.) added in HCCA (10 mg) dissolved in a volume of $1 \mathrm{~mL}$ of $\mathrm{ACN} / 0.1 \%$ TFA: $\mathrm{H}_{2} \mathrm{O}(2: 1, \mathrm{v} / \mathrm{v})$.

Acquisition was realized using a $337 \mathrm{~nm}$, pulsed nitrogen laser, with a repetition rate of $50 \mathrm{~Hz}$. For images reconstruction the FlexImaging v. 1.0.6.0 software (Bruker Daltonics, Bremen, DE) was used. For positive mode, 12000 points covering the whole slice with 100 laser shots per position were scanned. From each position the software measures an average mass spectrum with its coordinates on the slice. Images were reconstructed using the same parameters for treated and non-treated sections.

\section{Nano ESI-QqTOF/MS and MS/MS experiments}

Analyses were performed on a QSTAR pulsar quadrupole time-of-flight mass spectrometer (MDS Sciex) equipped with a nanoelectrospray ion source (Proxeon Biosystems). Spectra were acquired in both the positive and negative modes after dissolving compounds in $\mathrm{CH}_{3} \mathrm{OH} / \mathrm{CHCl}_{3}(9: 1, \mathrm{v} / \mathrm{v})$. Collision energy was set at $45 \mathrm{eV}$ for collisional activation. Precursor ion scan experiments were performed in both the positive and negative mode, (5 scans at $800 \mathrm{~ms}$ ) with 0.5 a.m.u. increments, at unit resolution for the Q1 quadrupole. Acquisitions were done with Analyst QS software and treated with the same software or "m/z" (Genomic Solutions Inc.). For lithium adducts ions, samples were spiked using a $2 \mathrm{mM} \mathrm{LiCl}$ solution.

\section{Immunohistochemistry}

Immunohistochemistry experiments were performed according to classical protocols. Briefly, tissues were placed in $0.1 \mathrm{M}$ PBS buffer ( $\mathrm{pH} 7.4$ ) at $4^{\circ} \mathrm{C}$ for 30 minutes, then incubated at room temperature with $500 \mu \mathrm{L}$ of a second buffer $(0.1 \mathrm{M}$ PBS / 1\% BSA / 1\% normal goat serum / 0,05\% triton X100) for 30 minutes. The same buffer was used to dilute 
the oxytocin peptide antibody (1/200), and incubation was performed for 80 minutes at $30^{\circ} \mathrm{C}$. After 3 times washing in PBS, sections were incubated with peroxidase-conjugated secondary antibody (anti-rabbit IgG 1/100 developed in goat; Jackson Immunoresearch Inc. Europe LTD) during 80 minutes at $30^{\circ} \mathrm{C}$. After another 3 washing steps, the sections were incubated in 3,3' diaminobenzidine tetrahydrochloride (DAB) with $0,05 \% \mathrm{H}_{2} \mathrm{O}_{2}$ for detection. The DAB reacts with the peroxydase group of the secondary antibody leading to a brown precipitate. Tissues were then, compared using microscopy after more washing in Phosphate buffer and ultrapure water.

The procedure and the characterization of the anti-oxytocin used were according the one from Salzet et al. (1993) ${ }^{23}$.

\section{RESULTS AND DISCUSSION}

The following organic solvents: chloroform, hexane, acetone, toluene and xylene were tested on rat brain tissue sections. Tissues were stored $\left(-80^{\circ} \mathrm{C}\right.$ storage) for periods ranging from freshly dissected to one year storage, from which signals for peptides/proteins were very weak when compared to freshly dissected slices. The main difficulty with these experiments was linked to variations between animals and in the chemical composition of the different areas of the brain. Thus, care was taken to analyze the same area of each section on adjacent sections. In order to obtain a statistical analysis, experiments were repeated at least 5 times for each parameter. The first set of experiments was performed using HCCA as matrix. In general for long storage, after treatment, the analyses revealed a signal increase in peptides/proteins as compared to untreated sample for all solvents. A more detailed inspection of the mass spectra clearly shows a major signal decrease in the mass range 500-1000 for all solvents (Figure 1). This effect is particularly visible in chloroform treated tissue. Signal loss in this region could be attributed to reduction of lipids by chloroform extraction which is in good agreement with 
the chemistry of lipid extraction ${ }^{24-26}$ and lipid direct analysis ${ }^{27,28}$. It must be noted that partial lipid removal simplifies the MALDI mass spectra in the low mass range, thus allowing the identification of low mass peptides that were masked by the high abundance of lipid peaks. As shown in Figure 1, the peak profiles are slightly different depending on the solvent use, which suggests specific extraction of certain classes of lipids depending on the treatment.

In order to study the increase of signal intensity in the mass ranges corresponding to proteins, experiments were repeated with sinapinic acid as a matrix. This experimental set confirmed the increase in peak intensities for the mass range 5000-30,000 with chloroform and xylene showing a particularly clear effect (Figure 2) in comparison to untreated tissues. Table 1 summarizes the averaged results for all experiments. From the mass spectra (Figure 2) increased intensity is clearly observed after solvent treatment of the tissue. Table 1 also shows an increase in the number of detected compounds. On average, 26 more compounds were detected after treatment with xylene and 21 more with chloroform, for an increase in detection of peptides/proteins of $44 \%$ and $34 \%$ respectively. A decrease in standard deviations and an improvement in reproducibility were registered after treatment of the tissue for all solvents tested. The same trend was observed when treating freshly dissected tissues. However, the effect was less significant for these tissues and was more dependent on the rat brain region probed, i.e. it presumably depending on the lipid versus peptides/proteins composition of the region. Hence, increase in protein detection is directly related to lipid decrease, presumably due to lipid extraction, giving easier access to intracellular proteins by breaching the cell membrane. In order to optimize protein analyses, detected peak numbers and intensities were studied as a function of the solvent volume used for the rinsing step. Volumes of 50 to $500 \mu \mathrm{L}$ were tested. Treatment times were not considered as a variable due to the high volatility of some solvents. Under our experimental conditions, we did not observe major differences with increased volumes. A solvent volume of $200 \mu \mathrm{L} / \mathrm{cm}^{2}$ appeared to be sufficient for optimal 
results. On the other hand, the washing procedure has to be repeated twice to get optimal reproducibility. Rinsing of the sample was preferred to dipping in bath of solvent to avoid loss of tissue, through detachment from the support. Since, ethanol tissue treatment was previously described by Schwartz et al. ${ }^{19}$ to remove salts, we therefore compared ethanol treatment to chloroform and xylene treatments (Figure 3). Our data shows that signal intensity, signal to noise ratio and the number of peaks were always higher using either xylene or chloroform.

Considering each of the solvent properties, we conclude that improved detection and reproducibility is related to the decreased lipid levels in the tissue sections. However, since low abundance peaks corresponding to lipids remain observable on the mass spectra (Figure 1), washing did not allow the total removal of lipids. We conclude that increased detection is most likely due to the opening of the lipidic bilayer and that the solvent acts more as a “peeling” agent. This effect would permit a better co-crystallization of peptides/proteins contained in the cytoplasm within the MALDI matrix crystals.

To evaluate the validity of this hypothesis, washing solutions were analyzed after tissue treatment. Five rinsing solutions of each solvent were collected after the tissue treatment. The solutions were evaporated under a $\mathrm{N}_{2}$ stream and dissolved in chloroform/methanol then analyzed by MALDI-TOF and nanoESI-QqTOF. MALDI-TOF analyses were performed with both HCCA and SA matrices. In none of the cases, did we observe peptide/protein peaks that would usually be seen in the tissue section as shown in Figure 4a for chloroform with HCCA as matrix. On the other hand, the presence of lipids was confirmed for all solvents. Also shown in Figure 4b for chloroform with HCCA, lipids peaks are observed in the 400-1000 mass range and signals around m/z 800 are characteristic of phospholipids. The large number of lipids detected in one extract suggests the presence of different class of lipids. A more detailed characterization of these lipids present in chloroform extract was undertaken on a nanoESI-QqTOF by studying their CID spectra. As previously described ${ }^{29-31}$, differentiation 
in lipid forms can be achieved on the basis of characteristic product ions. Phosphatidylinositol (PI) and lisophosphatidylinositol (LPI) present a specific fragment ion at $\mathrm{m} / \mathrm{z} 241$, plasmenylethanolamine (PlsEtn) and phosphatidylethanolamine (PtdEtn) at $\mathrm{m} / \mathrm{z}$ 196, phosphatidylcholine (PC) at m/z 184. By performing precursor ion scan mode analysis each form of lipids can be assigned. In the case of the phosphatidylserine family (PSer), only neutral loss allows the identification of these compounds. As neutral loss mode is not available on a QTOF instrument, lithium salts were used to form lithium adducts and obtain a characteristic fragment at m/z 192 as described by Ekroos et al $^{32}$. Figure 5 present the CID ion precursor spectra obtained for precursor ions corresponding to PC, PlsEtn, PtdEtn and PSer families. For each type of lipid, several compounds are identified. PlsEtn can be distinguished from PtdEtn on the base of the molecular mass and the absence of detection of the second acyl-group in MS/MS mass spectra (Figure 6a) as described in the work of Brouwers et $\mathrm{al}^{33}$. Position of the fatty acyl group on the glycerol backbone chain was elucidated according to the works of Hsu and Turk ${ }^{24-26}$ by performing CID parent ion scan as presented in example for PSer 18:0/22:6 (Figure 6b) and PI 16:0/20:4 (Figure 6c). Most abundant identified lipids are summarized by class in Table 2. Several sulfatides were also detected but in lower abundance (data not shown). For the other solvents including xylene, the same lipids were identified. As expected, the abundant detection of phospholipids confirms that treatments specifically remove lipids from tissue surface, especially membrane lipids. Moreover, PtdEtn and Pser are known to be present in high concentration in the inner monolayer of plasma membranes, while PC is dominant in the outer monolayer ${ }^{29}$. But, more specific lipids such as plasmenylethanolamine (PlsEtn) known to be very abundant in neuronal cells ${ }^{31}$ were also detected.

Finally, analyses of the wash solutions from treated tissue show that no peptides/proteins are extracted from the tissue. On the contrary, many phospholipids are 
present, from both the outer and inner cellular membranes, confirming the hypothesis that lipid bilayer opening by the solvent facilitates matrix access to intracellular peptides/proteins for co-crystallization. Tissue treatment with solvents as chloroform is advantageous when compared to other strategies ${ }^{19}$ based on the reduction of salts using ethanol or other types of alcohols. Indeed, using this approach in our experience, results in extraction of hydrophilic peptides/proteins and explains the reduction of hemoglobin signal ${ }^{19}$, whereas such a phenomenon is not observed with xylene/chloroform treatments as demonstrated by the washing solutions analysis. Peptides or proteins removal by solvent treatments must really be considered to prevent the potential loss of information during direct analysis of tissue.

Considering these results, increased detection limits of peptide/proteins can be obtained for tissue profiling in MALDI-MS without extraction of peptides/proteins. However, this does not mean that peptides/proteins do not migrate from their original location under the solvent treatment effect or that the tissue keeps its integrity. Knowing that solvents such as chloroform or acetone induced precipitation of proteins ${ }^{34}$, migration of proteins at the tissue surface by solvent dragging effects were examined. Indeed, direct tissue analysis of specific area and MALDI imaging of tissue sections fully require localization and tissue structure preservation. To confirm the latter, we used an approach based on tissue observations using optical microscopy, direct analysis of tissues and immunohistochemistry experiments. Microscopic examination of the tissue, after treatment and solvent evaporation, shows that the tissue section has turned white. However, no change in the tissue structure was observed demonstrating that microscope observations remain valid after tissue treatment (data not shown). To check delocalization we studied peptide/protein signals in specific locations of treated and non-treated tissue of rat brain, known to contain specific peptides/proteins. Spectra of treated samples do not show major differences compared to non-treated ones showing no delocalization of compounds. However, immunohistochemical validation is a 
more powerful strategy for comparative analysis. For immunohistochemistry experiments, two adjacent rat brain sections were used, one section being treated with solvent and the other remaining untreated. The direct analysis of a section has confirmed the presence of the oxytocin peptide (Mw= 1010,2 a.m.u) and protein precursor $(\mathrm{Mw}=12822,95$ a.m.u) in the tissue sections. Rabbit antibody against oxytocin was used on both sections. As shown in Figure 7 for treatment with chloroform, antibody labeling of the two sections is similar demonstrating same localization of the peptides and its precursor in the treated (Figure 7b) and non-treated (Figure 7a) sections. Similar results were obtained using xylene. Thus, treatment of the tissue sections does not generate any delocalization of peptides/proteins and can be used for MALDI imaging.

To study this matrix accessibility phenomenon using organic solvents, MALDI-MS imaging experiments were performed on tissues before and after treatment of adjacent rat brain sections. In this way, the potential of MALDI Imaging following organic solvent improvement without delocalization can be examined. Particular attention was given to older tissue sections in these experiments (at least 6 months conservation). As seen on the images obtain after scanning (Figure 8c), it is very difficult to recognize rat brain structures in these conserved tissues sections without treatment. Following treatment with chloroform, the sections turn white and brain structures appear more clearly. For these experiments either HCCA/ANI or sinapinic acid were used as matrix depending on the mass range of interest. HCCA/ANI was used to explore the low mass range corresponding to peptides ( $\mathrm{m} / \mathrm{z}<10000)$ whereas Sinapinic was used for proteins with $\mathrm{m} / \mathrm{z}>10,000$. For identified lipids, as expected, delocalization is observed with a decrease in the ion signal intensity. For peptides, as $\mathrm{m} / \mathrm{z}$ 1394 (Figure 8a) analyzed with HCCA/ANI effect of the tissue treatment is clear. Few ion signals with no correlated localization are observed from untreated tissues, while significant increase of signal is seen on the reconstructed images of chloroform treated tissues, with 
localization much more in relation with the structures of the region. Figure $8 \mathrm{~b}$ present the images reconstructed from the data collected after acquisition from two adjacent rat brains sections; the first one untreated and the second one washed with chloroform and with sinapinic acid as matrix. Considering higher mass protein, here $\mathrm{m} / \mathrm{z} 14306$, a remarkable increase in signal intensity is observed between untreated and chloroform treated samples. MALDI images of long conserved samples untreated and treated demonstrate clearly the effect of solvent treatment, on the signal increase and localization correlation improvement of peptides/proteins with no observed delocalization. 


\section{CONCLUSION}

Treatments with organic solvents such as chloroform, acetone, hexane, toluene or xylene are an effective and rapid method for signal enhancement in MALDI direct tissue profiling. Solvent treatment effects provide impressive results for archived tissues which prior to these treatments did not allow proper detection. These studies demonstrate that solvent treatments remove at least partially lipids from the tissue surface. Among all the tested solvents, chloroform and xylene have proven to lead to the higher increase in signal intensity and number of detected peptides/proteins. Compared to previous studies with ethanol, chloroform/xylene solvent, rinsing is more specific for lipid removal and does not generate any delocalization or extraction of most soluble peptides/proteins as tested by immunohistochemistry experiments. However, this treatment does not reduce salt adducts as alcohol treatments. Application of this protocol is suitable for direct analysis profiling on tissues as well as for MALDI imaging applications. Moreover, the results suggest that it is possible to detect, after organic rinsing treatments, compounds that were masked by lipids in the tissue, like peptides/proteins present in the cytoplasm. As lipids from the outer and the inner membranes are identified from the washing extracts, we can assume that treatment opens lipid bilayers increasing peptides/proteins access for the MALDI matrix. Mostly, solvent and in particular chloroform or acetone will open the membrane layers inducing precipitation of the proteins at the surface of the tissue resulting in co-crystallization between the matrix and the proteins. This aspect is confirmed by the white color of the tissue, suggesting precipitation. For old tissues, a layer is present at the surface of the tissue section, probably due to the degradation of lipids and possibly oxidation due to the presence of air. Treatment with chloroform or xylene probably removes this layer and partially non degraded lipids. Such treatments are a fast and efficient method for working on tissue stored for a long 
time in tissue banks and open the opportunity to work with old samples from patients with pathologies stored in hospital libraries.

\section{ACKNOWLEDGEMENTS}

Supported by grants from Centre National de la Recherche Scientifique (CNRS), Ministère de L’Education Nationale, de L’Enseignement Supérieur et de la Recherche (ACI Jeunes Chercheurs ACI JC4074 to I. Fournier), le Conseil Régional Nord-Pas de Calais to M. Wisztorski, and the Canadian Institutes of Health Research (CIHR to RD). Also supported by

a collaboration agreement between Bruker Daltonics $\mathrm{GmbH}$ and the Laboratoire de Neuroimmunologie des Annélides. The authors would like to acknowledge the Proteomic Plateforme of Lille, IFR 118 and would like to thank Dr. A.S. Woods for her critical reading. 


\section{REFERENCES}

(1) Hillenkamp, F.; Karas, M.; Beavis, R. C.; Chait, B. T. Anal Chem 1991, 63, 1193A1203A.

(2) Karas, M.; Hillenkamp, F. Anal Chem 1988, 60, 2299-2301.

(3) Fournier, I.; Day, R.; Salzet, M. Neuro Endocrinol Lett 2003, 24, 9-14.

(4) Chaurand, P.; Caprioli, R. M. Electrophoresis 2002, 23, 3125-3135.

(5) Caprioli, R. M.; Farmer, T. B.; Gile, J. Anal Chem 1997, 69, 4751-4760.

(6) Chaurand, P.; Sanders, M. E.; Jensen, R. A.; Caprioli, R. M. Am J Pathol 2004, 165, 1057-1068.

(7) Crecelius, A. C.; Williams, B.; Cornett, D. S.; Dawant, B. M.; Bodenheimer, R. E.; Lepage, M.; Niermann, K. J.; Caprioli, R. M., Nashville TE, USA 2004.

(8) Stoeckli, M.; Chaurand, P.; Hallahan, D. E.; Caprioli, R. M. Nat Med 2001, 7, 493496.

(9) Touboul, D.; Piednoel, H.; Voisin, V.; De La Porte, S.; Brunelle, A.; Halgand, F.; Laprevote, O. Eur J Mass Spectrom (Chichester, Eng) 2004, 10, 657-664.

(10) Tempez, A.; Ugarov, M.; Egan, T.; Schultz, J. A.; Novikov, A.; Della-Negra, S.; Lebeyec, Y.; Pautrat, M.; Caroff, M.; Smentkowski, V. S.; Wang, H. Y.; Jackson, S. N.; Woods, A. S. J Proteome Res 2005, 4, 540-545.

(11) Chaurand, P.; Schwartz, S. A.; Reyzer, M. L.; Caprioli, R. M. Toxicol Pathol 2005, 33, 92-101.

(12) Hsieh, Y.; Casale, R.; Fukuda, E.; Chen, J.; Knemeyer, I.; Wingate, J.; Morrison, R.; Korfmacher, W. Rapid Commun Mass Spectrom 2006, 20, 965-972.

(13) Reyzer, M. L.; Hsieh, Y.; Ng, K.; Korfmacher, W. A.; Caprioli, R. M. J Mass Spectrom 2003, 38, 1081-1092.

(14) Rohner, T. C.; Staab, D.; Stoeckli, M. Mech Ageing Dev 2005, 126, 177-185.

(15) Wang, H. Y.; Jackson, S. N.; McEuen, J.; Woods, A. S. Anal Chem 2005, 77, 66826686.

(16) Bunch, J.; Clench, M. R.; Richards, D. S. Rapid Commun Mass Spectrom 2004, 18, 3051-3060.

(17) Caldwell, R. L.; Caprioli, R. M. Mol Cell Proteomics 2005, 4, 394-401.

(18) Chaurand, P.; Schwartz, S. A.; Caprioli, R. M. J Proteome Res 2004, 3, 245-252.

(19) Schwartz, S. A.; Reyzer, M. L.; Caprioli, R. M. J Mass Spectrom 2003, 38, 699-708.

(20) Bligh, E. G.; Dyer, W. J. Can J Biochem Physiol 1959, 37, 911-917.

(21) Folch, J.; Lees, M.; Sloane Stanley, G. H. J Biol Chem 1957, 226, 497-509.

(22) Ferraz, T. P.; Fiuza, M. C.; Dos Santos, M. L.; Pontes De Carvalho, L.; Soares, N. M. J Biochem Biophys Methods 2004, 58, 187-193.

(23) Salzet, M.; Wattez, C.; Slomianny, M. C. Comp Biochem Physiol Comp Physiol 1993, 104, 75-81.

(24) Hsu, F. F.; Turk, J. J Am Soc Mass Spectrom 2000, 11, 892-899.

(25) Hsu, F. F.; Turk, J. J Am Soc Mass Spectrom 2000, 11, 986-999.

(26) Hsu, F. F.; Turk, J. J Am Soc Mass Spectrom 2003, 14, 352-363.

(27) Jackson, S. N.; Wang, H. Y.; Woods, A. S. Anal Chem 2005, 77, 4523-4527.

(28) Jackson, S. N.; Wang, H. Y.; Woods, A. S. J Am Soc Mass Spectrom 2005, 16, $2052-$ 2056.

(29) Han, X.; Gross, R. W. Mass Spectrom Rev 2005, 24, 367-412.

(30) Murphy, R. C.; Fiedler, J.; Hevko, J. Chem Rev 2001, 101, 479-526.

(31) Pulfer, M.; Murphy, R. C. Mass Spectrom Rev 2003, 22, 332-364. 
(32) Ekroos, K.; Chernushevich, I. V.; Simons, K.; Shevchenko, A. Anal Chem 2002, 74, 941-949.

(33) Brouwers, J. F.; Vernooij, E. A.; Tielens, A. G.; van Golde, L. M. J Lipid Res 1999, 40, 164-169.

(34) Jiang, L.; He, L.; Fountoulakis, M. J Chromatogr A 2004, 1023, 317-320. 
Table 1. Average number of detected compounds, standard deviation and calculated increase detection for peptides/proteins of $\mathbf{m} / \mathbf{z}>5000$ determined from the mass spectra recorded on untreated rat brain sections versus organic solvent treated ones.

$\begin{array}{ccccc}\text { Treatment } & \mathbf{n}^{\mathbf{a}} & \begin{array}{c}\text { Number of detected } \\ \text { compounds }\end{array} & \begin{array}{c}\text { Standard } \\ \text { deviation (\%) }\end{array} & \begin{array}{c}\text { Increase in } \\ \text { detection (\%) }\end{array} \\ \text { Chloroform } & 10 & 81 & 22 & 34 \\ \text { Hexane } & 5 & 75 & 28 & 25 \\ \text { Toluene } & 5 & 68 & 22 & 13 \\ \text { Xylene } & 5 & 86 & 13 & 44 \\ \text { Acetone } & 5 & 64 & 29 & 7 \\ \text { Untreated } & 10 & 60 & 34 & 0\end{array}$

${ }^{a}$ number of experiments 
Table 2. Assignment of several phospholipids using positive or negative precursor ion scanning and product ion mode experiments on nanoESI-QqTOF by analysis of chloroform rinsing extracts of rat brain tissue sections

\begin{tabular}{|c|c|c|c|}
\hline $\mathbf{m} / \mathbf{z}$ & Polarity & Identified Lipid & Precursor Ion \\
\hline 569.5 & - & $16: 1-\mathrm{LPI}^{\mathrm{a}}$ & \multirow{8}{*}{$\begin{array}{c}\mathrm{m} / \mathrm{z} 241 \text { characteristic } \\
\text { product ion of }[\mathrm{M}-\mathrm{H}]^{-} \mathrm{PI} \\
\text { and LPI families }\end{array}$} \\
\hline 571.5 & - & 16:0-LPI & \\
\hline 599.5 & - & 18:0-LPI & \\
\hline 619.5 & - & 20:4-LPI & \\
\hline 655.5 & - & $22: 0-\mathbf{P I}^{\mathrm{b}}$ & \\
\hline 857.5 & - & 16:0/20:4-PI & \\
\hline 885.5 & - & 18:0/20:4-PI & \\
\hline 909.5 & - & 40:6-PI & \\
\hline 700.7 & - & 34:1-PlsEtn ${ }^{c}$ & \multirow{10}{*}{$\begin{array}{c}\text { m/z } 196 \text { characteristic } \\
\text { product ion of }[\mathrm{M}-\mathrm{H}]^{-} \\
\text {PlsEtn and PtdEtn } \\
\text { families }\end{array}$} \\
\hline 716.5 & - & 34:1-PtdEtn ${ }^{d}$ & \\
\hline 726.5 & - & 36:2-PlsEtn & \\
\hline 742.5 & - & 36:2-PtdEtn & \\
\hline 746.5 & - & 16:0/22:6-PlsEtn & \\
\hline 750.5 & - & 38:4-PlsEtn & \\
\hline 754.5 & - & 38:2-PlsEtn & \\
\hline 766.5 & - & 18:0/20:4-PtdEtn & \\
\hline 774.5 & - & 40:6-PlsEtn & \\
\hline 790.5 & - & 18:0/22:6-PtdEtn & \\
\hline 734.5 & + & $16: 0 / 16: 0-P C^{\mathrm{e}}$ & \multirow{7}{*}{$\begin{array}{c}\mathrm{m} / \mathrm{z} 184 \text { characteristic } \\
\text { product ion of }[\mathrm{M}+\mathrm{H}]^{+} \\
\text {PC }\end{array}$} \\
\hline 760.5 & + & 16:0/18:1-PC & \\
\hline 790.5 & + & 36:0-PC & \\
\hline 806.5 & + & 38:6-PC & \\
\hline 810.5 & + & 38:4-PC & \\
\hline 814.5 & + & 38:2-PC & \\
\hline 834.5 & + & 18:0/22:6-PC & \\
\hline 768.5 & + & 34:1-PSer & \multirow{6}{*}{$\begin{array}{c}\mathrm{m} / \mathrm{z} 192 \text { characteristic } \\
\text { product ion of }[\mathrm{M}+\mathrm{Li}]^{+} \\
\text {PSer }^{\mathrm{f}}\end{array}$} \\
\hline 796.5 & + & 36:1-PSer & \\
\hline 823.5 & + & 38:2-PSer & \\
\hline 843.0 & + & 18:0/22:6-PSer & \\
\hline 851.5 & + & 40:2-PSer & \\
\hline 879.5 & + & 42:2-PSer & \\
\hline
\end{tabular}



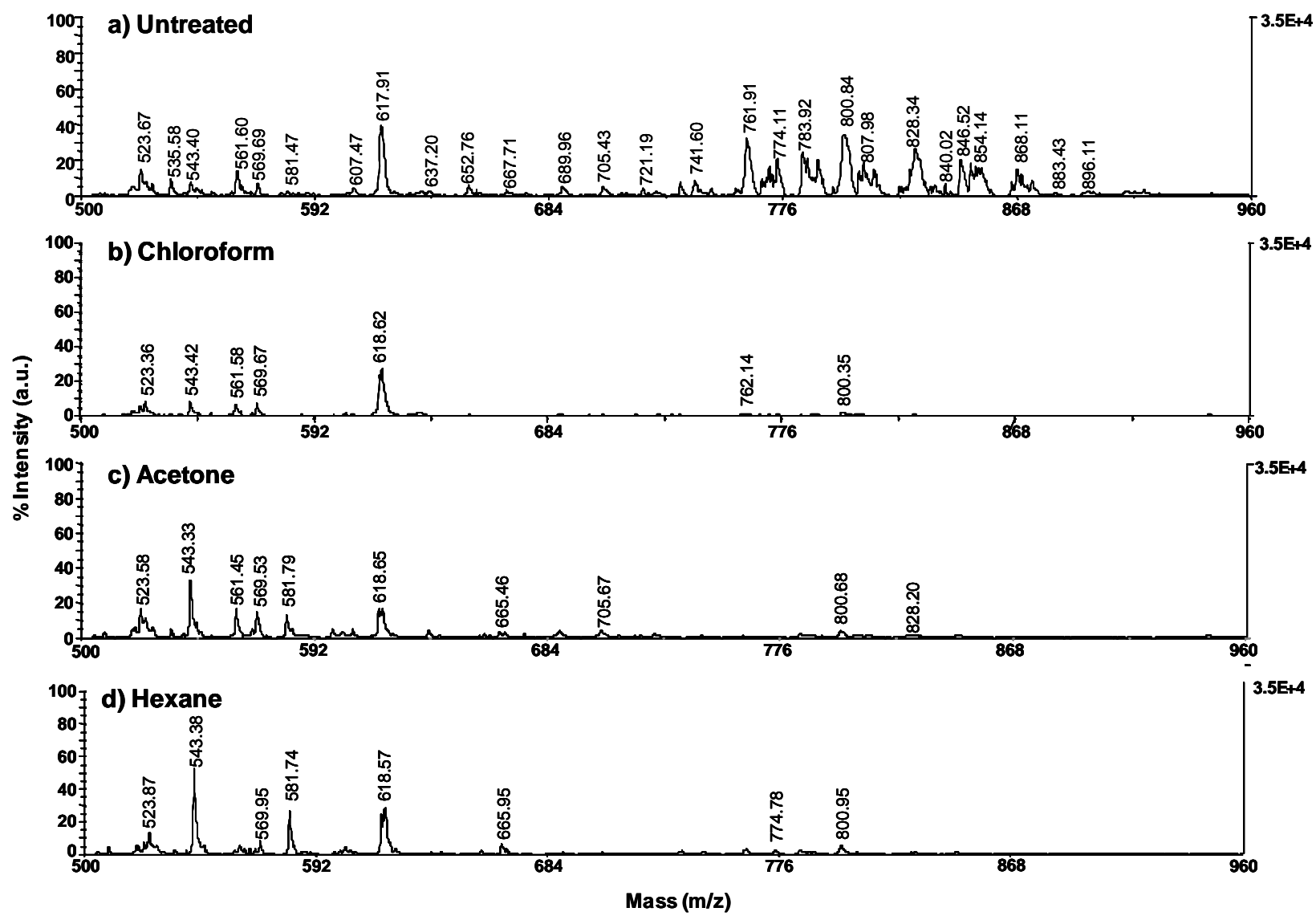

Figure 1 : Low mass range region of the MALDI-TOF mass spectra resulting from the direct analysis in linear positive mode with HCCA as matrix of rat brain tissue sections from a tissue block conserved 6 months at $-80^{\circ} \mathrm{C}$, a) untreated sample, after tissue treatment with b) chloroform, c) acetone and d) hexane 

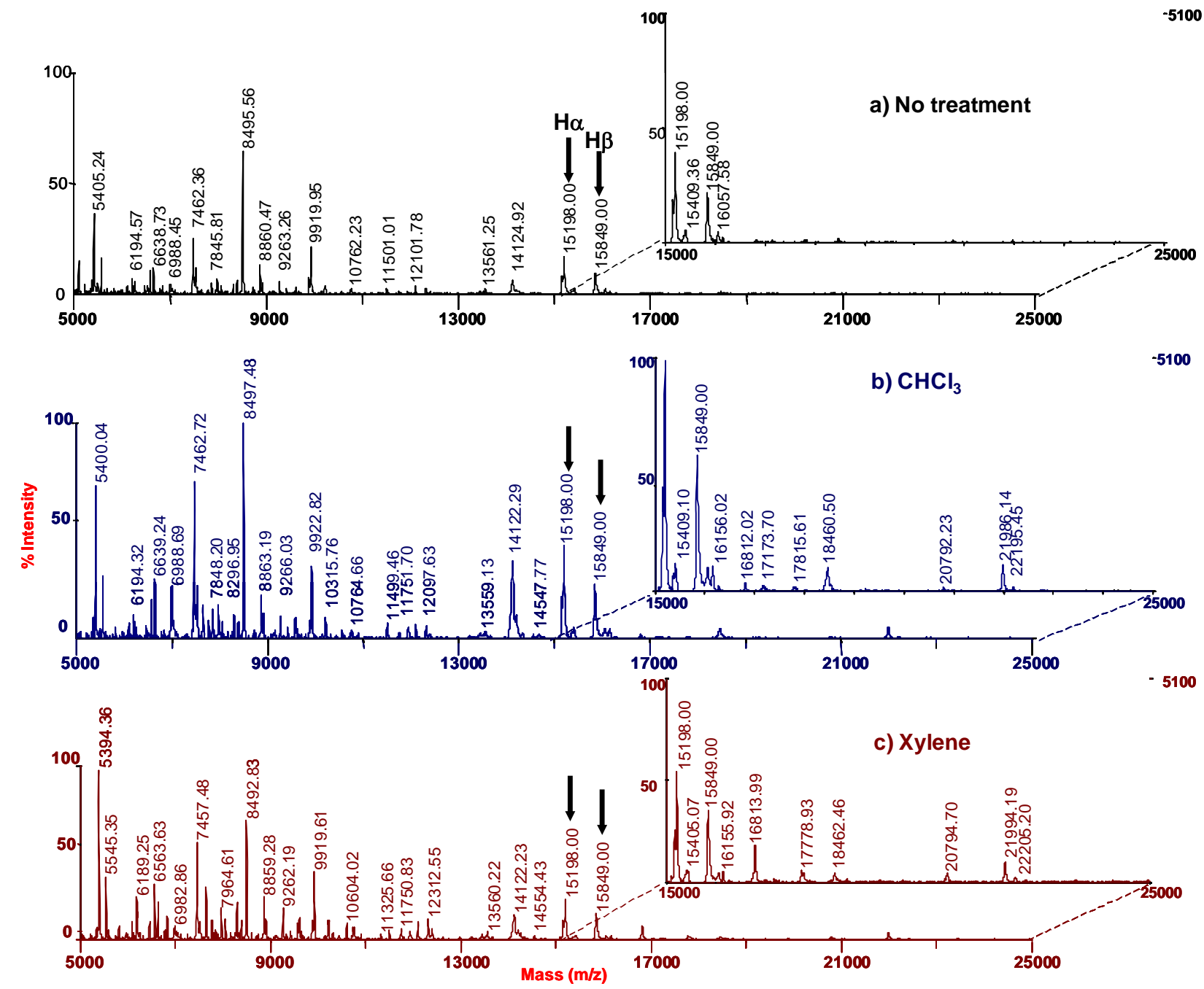

Figure $2: \mathrm{m} / \mathrm{z}>5000$ region of the MALDI-TOF mass spectra resulting from the direct analysis in linear positive ion mode with sinapinic acid as matrix of rat brain tissue sections from a tissue block conserved 6 months at $-80^{\circ} \mathrm{C}$, a) untreated sample, after tissue treatment with b) chloroform and c) xylene (the arrows indicate the peaks corresponding to hemoglobin $\alpha$ chain (major) or $\mathrm{H} \alpha$ and hemoglobin $\beta$ chain (major) or $\mathrm{H} \beta$ used as internal calibrants). 


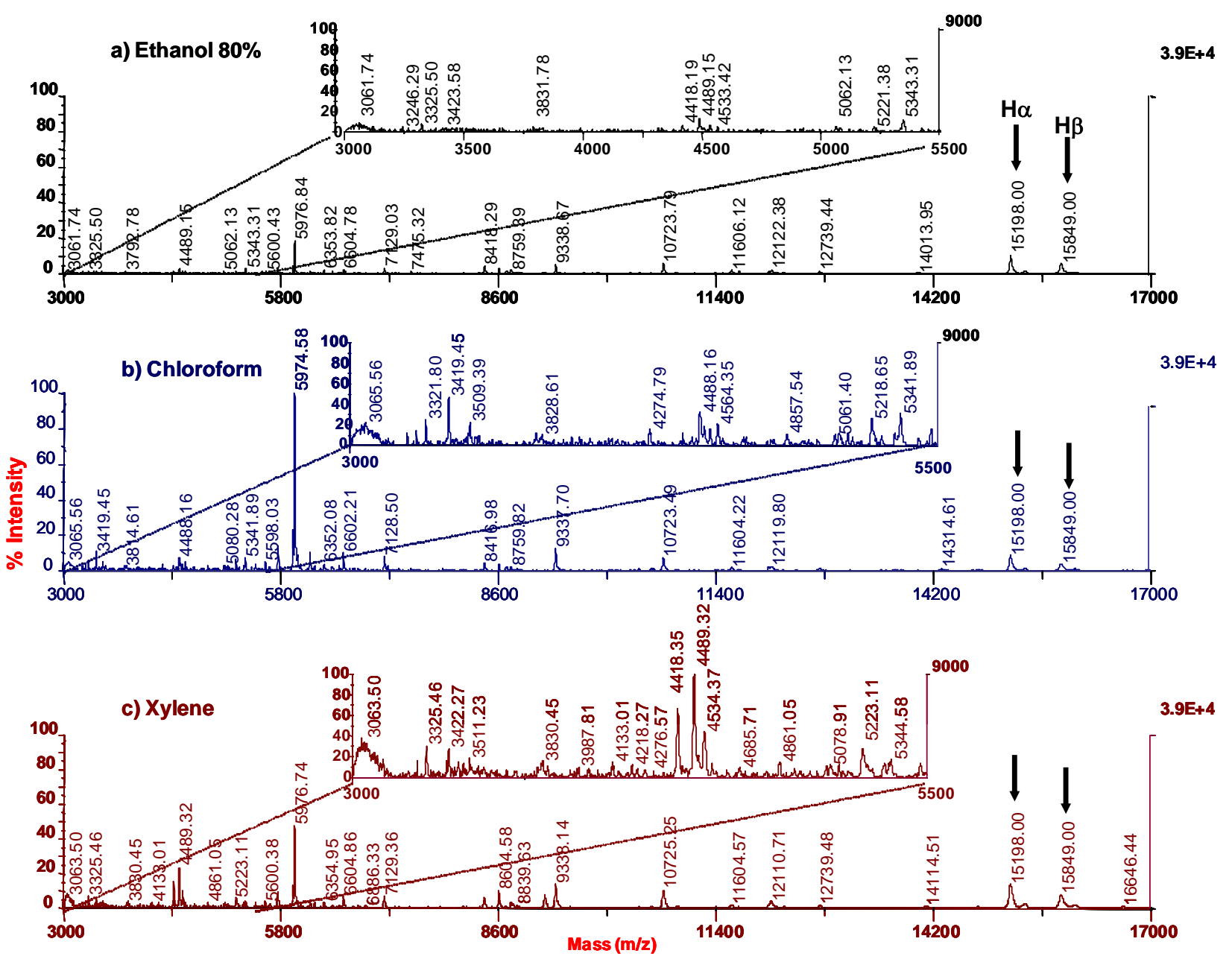

Figure $3: \mathrm{m} / \mathrm{z}>3000$ region of the MALDI-TOF mass spectra resulting from the direct analysis in linear positive ion mode with sinapinic acid as matrix of rat brain tissue sections from a tissue block conserved 6 months at $-80^{\circ} \mathrm{C}$, after tissue treatment with a) ethanol $80 \%$ b) chloroform and c) xylene (the arrows indicate the peaks corresponding to hemoglobin $\alpha$ chain (major) or $\mathrm{H} \alpha$ and hemoglobin $\beta$ chain (major) or $\mathrm{H} \beta$ used as internal calibrants). 


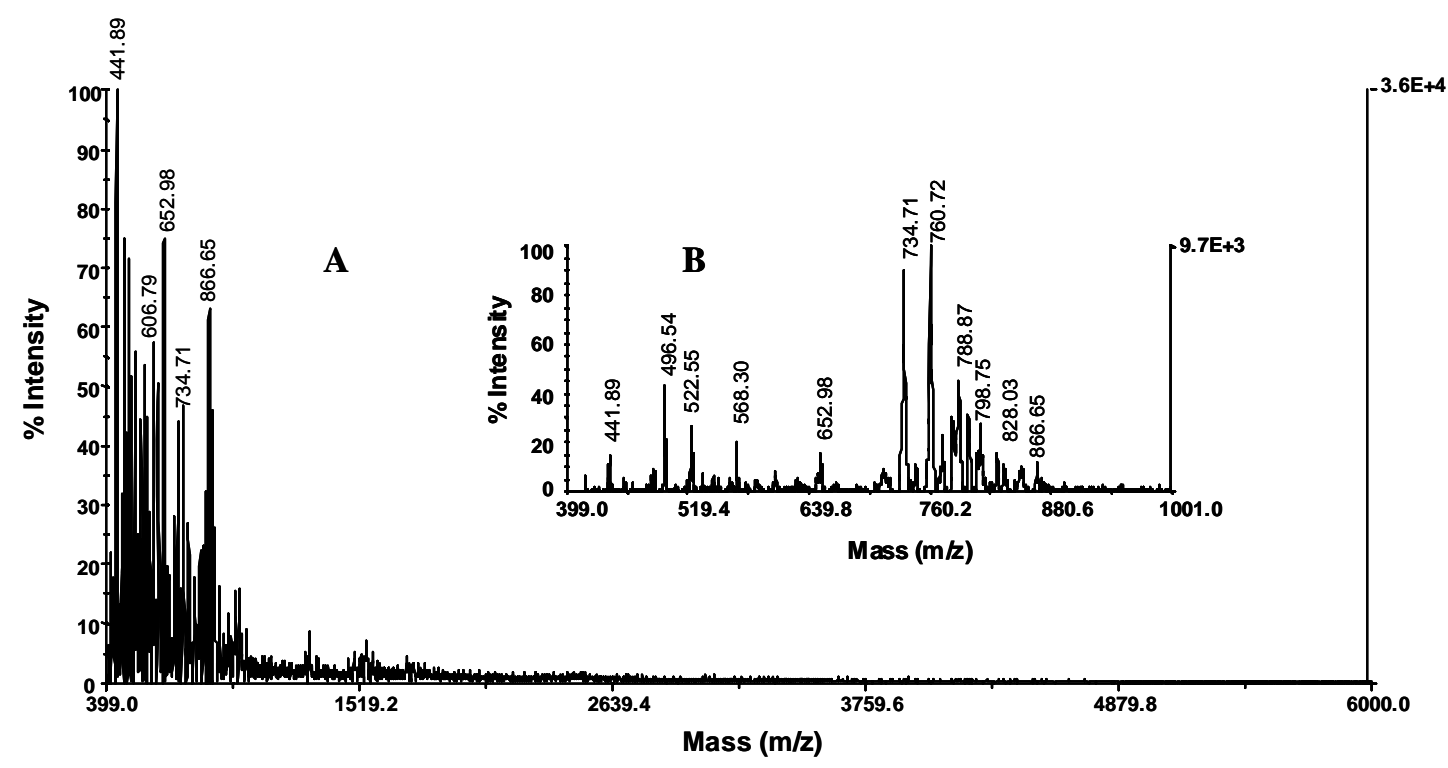

Figure 4. MALDI-TOF mass spectra using HCCA as matrix in the linear positive mode of the chloroform rinsing solution collected after tissue treatment. a) $400-6000 \mathrm{~m} / \mathrm{z}$ and b) $400-1000 \mathrm{~m} / \mathrm{z}$. 

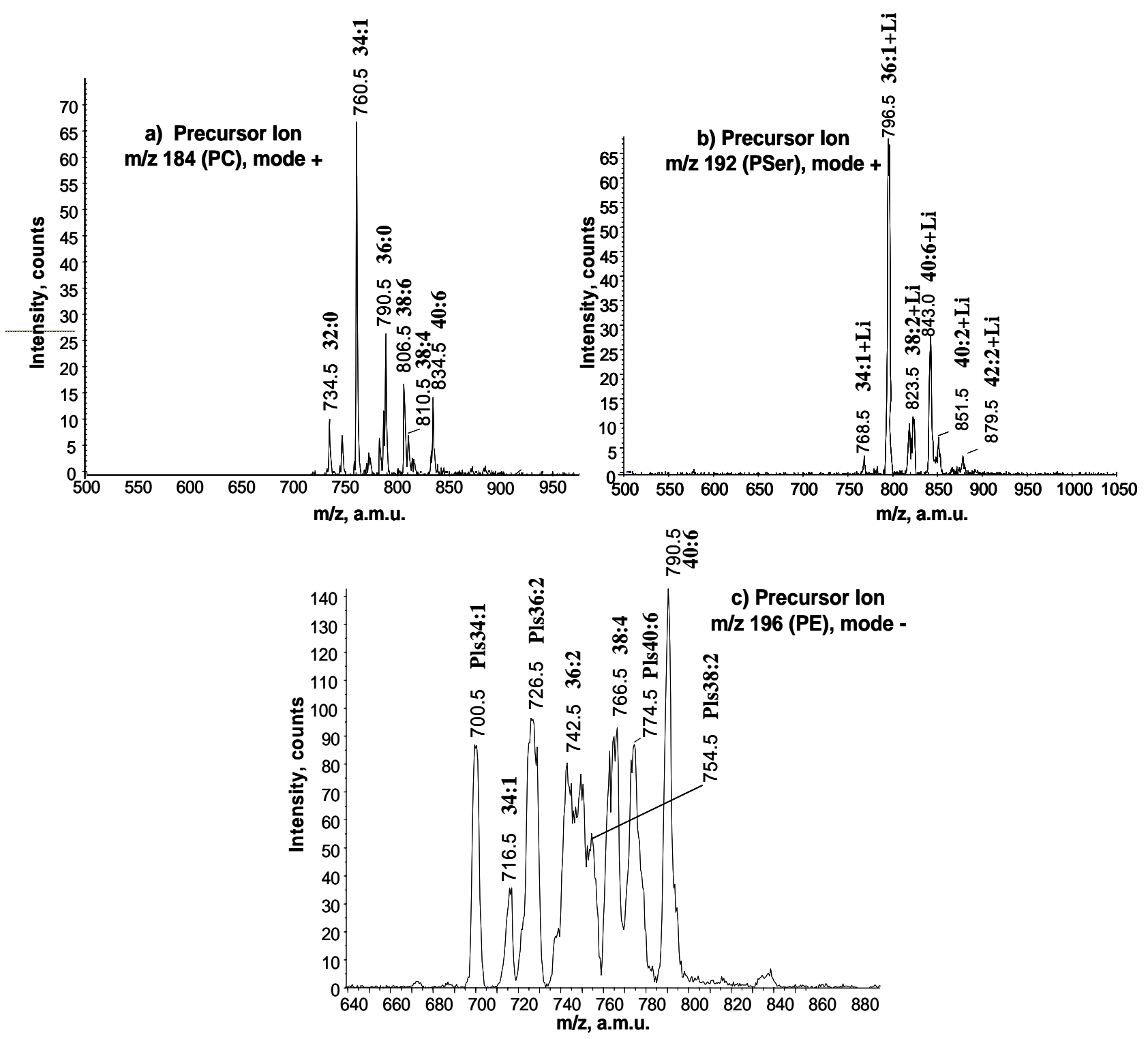

Figure 5 : CID precursor ion spectra using nanoESI-QqTOF by analyzing the extracts collected after tissue treatment with chloroform for a) m/z 184 (phosphatidylcholine) in positive mode, b) m/z 192 (phophatidylserine) with lithium adducts in positive mode and c) m/z 196 (phosphatidylethanolamine or plasmonylethanolamine) in negative mode. 

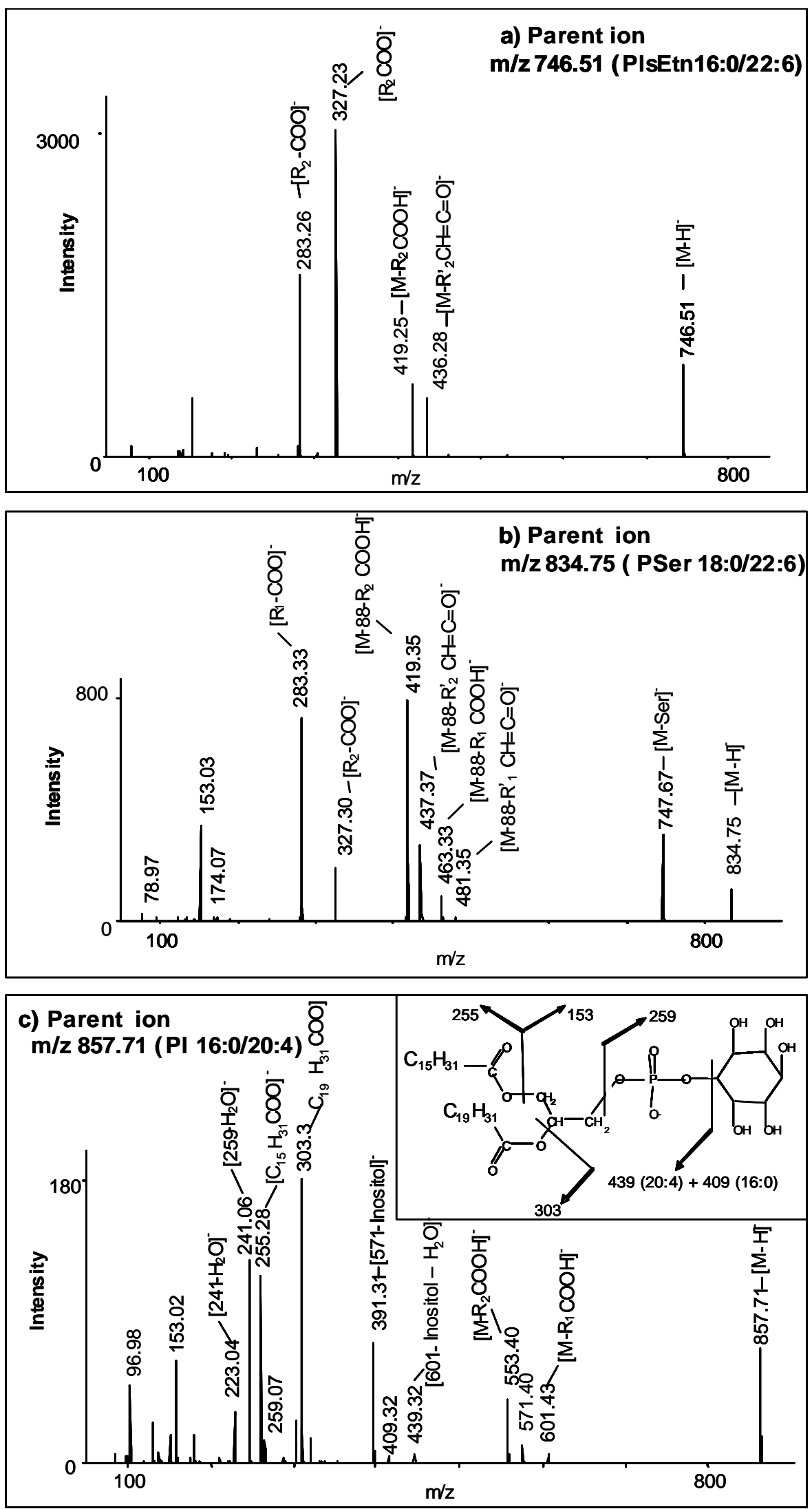

Figure 6 : CID product ion spectra obtained on a nanoESI-QqTOF by analyzing the extracts collected after tissue treatment with chloroform. (a) parent ion $\mathrm{m} / \mathrm{z} 746.5$ identified as PlsEtn 16:0/22:6, (b) parent ion $\mathrm{m} / \mathrm{z}$ 834.7 PS 18:0/22:6 and (c) parent ion $\mathrm{m} / \mathrm{z}$ 857.71 identified as PI 16:0/20:4. 

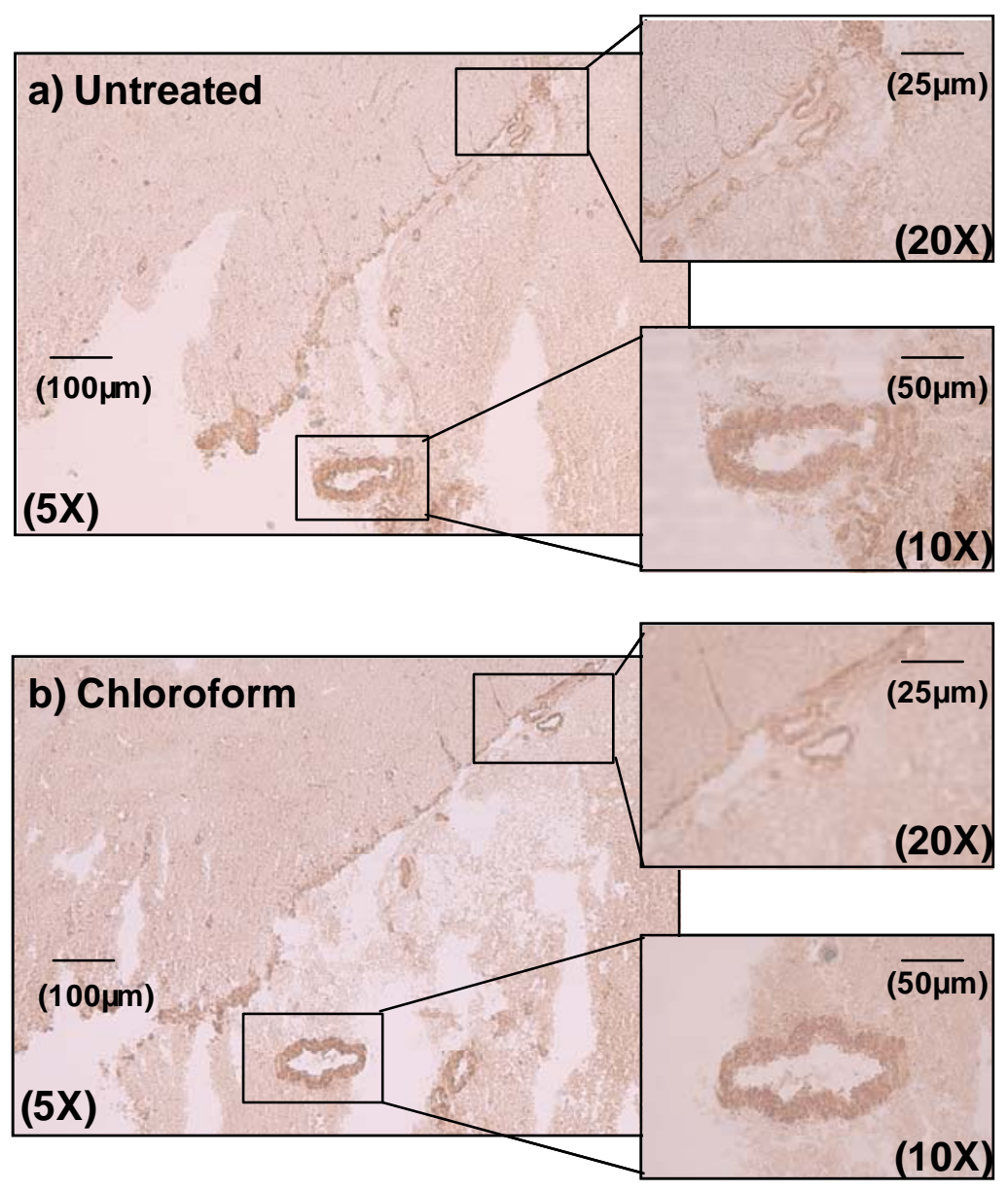

Figure 7: immunohistochemistry staining for antibody directed against oxytocin of two adjacent rat brain sections (a) untreated section and (b) rinsed with chloroform 

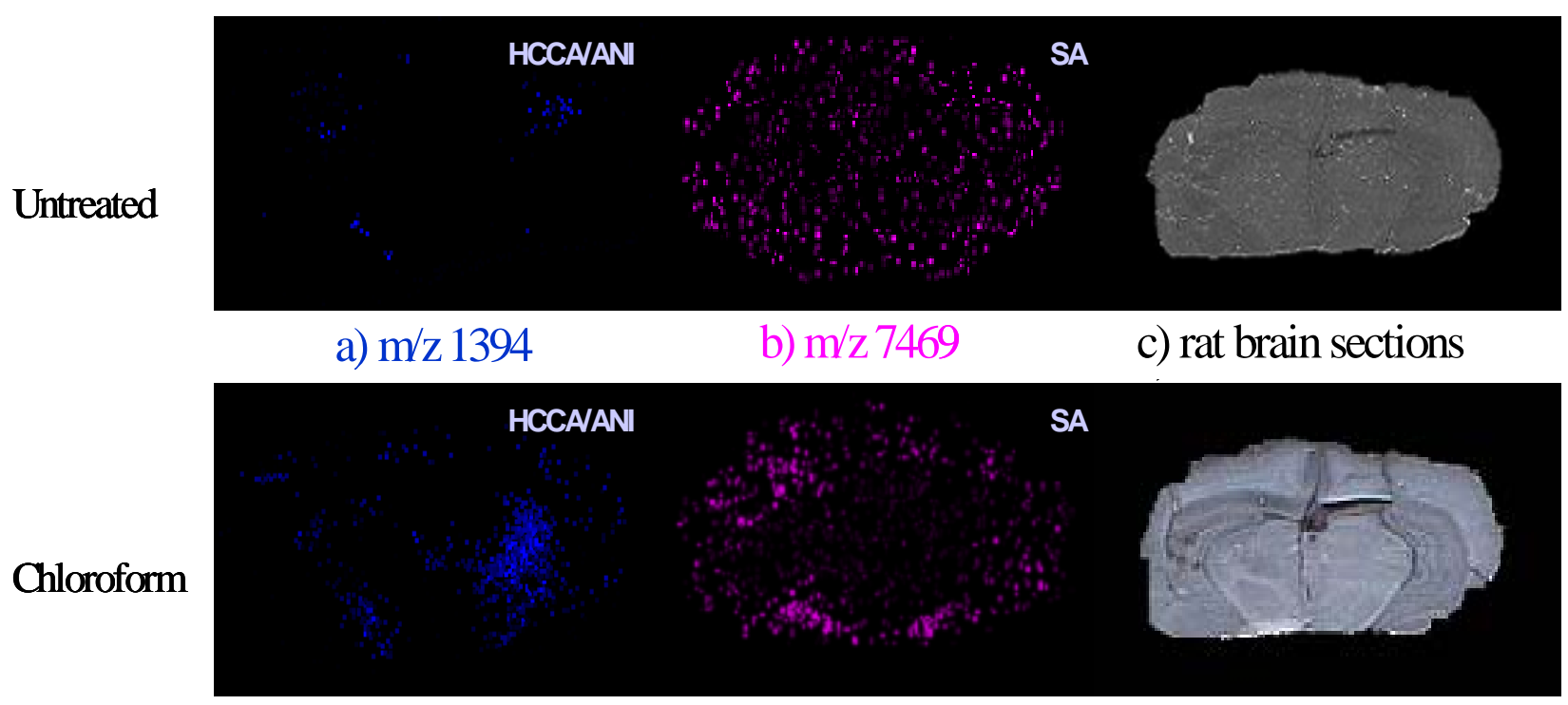

Figure 8. MALDI-LIFT-TOFTOF molecular images reconstructed from the data obtained by scanning two adjacent rat brain sections untreated (upper panel) and chloroform treated (lower panel) a) for $\mathrm{m} / \mathrm{z} 1394$ with HCCA/ANI as matrix, b) for $\mathrm{m} / \mathrm{z}$ 14306 with SA as matrix compared to $\mathrm{c}$ ) pictures of the sections before matrix deposition for MALDI analysis 